\title{
KINERJA PENYULUH KELUARGA BERENCANA PADA DINAS PENGENDALIAN PENDUDUK DAN KELUARGA BERENCANA KOTA MAKASSAR
}

\section{THE PERFORMANCE OF FAMILY PLANNING COUNSELORS TOWARDS DEPARTMENT OF POPULATION CONTROL AND FAMILY PLANNING IN MAKASSAR CITY}

\author{
Rohana Thahier ${ }^{1}$ dan Rima Melati Haris ${ }^{2}$ \\ ${ }^{1}$ Sekolah Tinggi Ilmu Administrasi-Lembaga Administrasi Negara, Makassar \\ email: rohana.thahier@yahoo.com \\ ${ }^{2}$ Badan Pusat Statistik Kota Makassar \\ email: rimelatifaharis31@gmail.com
}

\begin{abstract}
Abstrak
Penyuluh keluarga berencana merupakan faktor penting di dalam menjalankan program keluarga berencana akan tetapi kinerja penyuluh keluarga berencana pada Dinas Pengendalian Penduduk dan Keluarga Berencana Kota Makassar masih belum optimal. Berdasarkan permasalahan tersebut, maka penelitian ini bertujuan untuk mengetahui dan menganalisis kinerja penyuluh keluarga berencana pada Dinas Pengendalian Penduduk dan Keluarga Berencana Kota Makassar. Penelitian ini menggunakan metode kualitatif yang bersifat deskriptif dengan menggunakan metode pengumpulan data yaitu wawancara, telaah dokumen, dan observasi. Adapun instrument pengumpulan data yang digunakan yaitu pedoman wawancara, pedoman telaah dokumen dan pedoman observasi serta teknik analisis data dengan cara reduksi data, penyajian data, menarik kesimpulan, dan verifikasi. Setelah itu menguji keabsahan data dengan Teknik triangulasi. Hasil penelitian menunjukkan bahwa kinerja penyuluh keluarga berencana secara keseluruhan berada dalam kategori baik namun masih ada beberapa indikator yang perlu ditingkatkan untuk memaksimalkan kinerja penyuluh keluarga berencana.
\end{abstract}

Kata kunci : Kinerja, Kinerja Penyuluh Keluarga Berencana, Keluarga Berencana

\begin{abstract}
Family planning counsellors are an important factor in carrying out family planning programs, but the performance of family planning counsellors towards Department of Control of Population and Family Planning in Makassar City are still not optimal. Based on these problems, this research aims to determine and analyse the performance of family planning counsellors at the Department of Control of Population and Family Planning in Makassar. The research method used in this research is descriptive quality method. Data collection methods used in this research are interviews, document review and observation. Meanwhile, data collection instruments used in this research are interview guidelines, guidelines for reviewing documents and observation guidelines. Moreover, data analysis techniques used in this research are conducted by means of data reduction, data presentation, conclusions drawing and verification. After that, the validity of the data is tested by using the triangulation technique. The results of this research indicated that the overall performance of family planning counsellors was in a
\end{abstract}


good category but there were still several indicators that need to be improved to maximize the performance of family planning counsellors.

Keywords: Performance, Performance of Family Planning Counsellors, Family Planning

\section{PENDAHULUAN}

Organisasi merupakan suatu organisme yang harus terus menerus tumbuh secara kuantitatif maupun kualitatif. Kemampuan tumbuh ini memungkinkannya tangguh bukan saja dalam mempertahankan eksistensinya akan tetapi juga dalam mengembangkan dirinya secara mantap dalam rangka pencapaian tujuan.

Di era globalisasi sekarang ini, mewujudkan pemerintahan yang baik (good governance) menjadi suatu hal yang tidak dapat ditawar lagi keberadaannya dan mutlak terpenuhi. Prinsip-prinsip pemerintahan yang baik meliputi antara lain: (1) akuntabilitas (accountability) yang diartikan sebagai kewajiban untuk mempertanggungjawabkan kinerjanya; (2) keterbukaan dan transparansi (openness and transparency) dalam arti masyarakat tidak hanya dapat mengakses suatu kebijakan tetapi juga ikut berperan dalam proses perumusannya; (3) ketaatan pada hukum, dalam arti seluruh kegiatan didasarkan pada aturan hukum yang berlaku dan aturan hukum tersebut dilaksanakan secara adil dan konsisten; dan (4) partisipasi masyarakat dalam berbagai kegiatan pemerintahan umum dan pembangunan.

Dalam konteks ini, penerapan prinsip-prinsip "good governance" dalam pengelolaan pemerintahan menjadi suatu tuntutan utama, oleh karena masyarakat mulai kritis dalam memonitor dan mengevaluasi manfaat serta nilai yang diperoleh atas pelayanan dari instansi pemerintah. Disisi lain, pengukuran keberhasilan maupun kegagalan instansi pemerintah dalam menjalankan tugas pokok dan fungsinya sulit dilakukan secara objektif, disebabkan oleh karena belum diterapkannya sistem pengukuran kinerja, yang dapat menginformasikan tingkat keberhasilan secara objektif dan terukur dari pelaksanaan program-program disuatu instansi pemerintah.

Akhir-akhir ini pembicaraan tentang sumber daya manusia semakin terdengar. Hal ini tidak lepas dari kesadaran bersama bahwa manusia tidak hanya sebagai penikmat pembangunan. Di samping itu muncul juga kesadaran bahwa pembangunan tidak hanya bisa tergantung pada sumber daya alam. Beberapa ahli sepakat bahwa pembangunan di Indonesia juga sudah semestinya mengandalkan 
sumber daya manusia. Dengan tersedianya sumber daya yang memadai dalam arti kualitas dan kuantitas, maka tantangan di masa mendatang akan bisa diatasi dengan baik.

Berbicara mengenai kinerja dan pencapaian tujuan organisasi tidak terlepas dari siapa yang ada dan menjalankan organisasi tersebut, tidak lain adalah manusia itu sendiri. Sebagai unsur organisasi, manusia memiliki peran yang sangat penting dalam menjalankan fungsinya dalam rangka kemajuan organisasi. Potensi setiap individu yang ada dalam organisasi harus dapat dimanfaatkan sebaik-baiknya, sehingga mampu memberikan hasil yang maksimal. Di mana keberhasilan organisasi sangat tergantung pada peran manusia di dalamnya karena manusia sebagai sumber daya yang potensial dan merupakan sumber kekuatan untuk menggerakkan roda aktivitas organisasi.

Kinerja dalam organisasi merupakan jawaban dari berhasil atau tidaknya tujuan organisasi yang telah ditetapkan sebelumnya. Para atasan sering tidak memperhatikan kecuali situasi organisasinya sudah amat buruk atau segala sesuatu jadi serba salah. Terlalu sering seorang pimpinan tidak mengetahui betapa buruknya kinerja pegawainya telah merosot sehingga instansi menghadapi krisis yang serius.

Sumber daya terpenting suatu organisasi adalah sumber daya manusia. Sumber Daya Manusia merupakan elemen dalam organisasi yang memberikan tenaga, bakat, kreativitas, dan usaha mereka dalam organisasi. Dalam Konteks Organisasi Publik di Indonesia diselenggarakan Manajemen ASN untuk melakukan pengaturan Sumber daya manusia yang ada di dalam sebuah organisasi publik. Pengaturan Manajemen PNS bertujuan untuk menghasilkan PNS yang profesional, memiliki nilai dasar, etika profesi, bebas dari intervensi politik, bersih dari praktek korupsi, kolusi, dan nepotisme dalam rangka pelaksanaan tugas pelayanan publik, tugas pemerintahan, dan tugas pembangunan tertentu.

Kemajuan sebuah organisasi dapat dilihat melalui pencapaian target-target yang telah ditetapkan sebelumnya. Mengingat peran manusia yang cukup dominan tersebut, maka segala upaya akan dilakukan untuk menciptakan desain sistem dan mengatur kinerja pegawai.

Di Negara berkembang, masalah utama yang sering terjadi yaitu masalah tingginya laju pertumbuhan penduduk. Laju pertumbuhan penduduk di Indonesia semakin hari semakin meningkat. Pada tahu 2018 jumlah penduduk Indonesia sudah 
mencapai 266.927.712 jiwa. Untuk dapat mengatasi beberapa masalah penyebab terjadinya laju pertumbuhan penduduk pemerintah melakukan program keluarga berencana yang tertuang dalam Peraturan Pemerintah Nomor 87 Tahun 2014 tentang Perkembangan Kependudukan dan Pembangunan Keluarga, Keluarga Berencana, dan Sistem Informasi Keluarga. Program Keluarga Berencana merupakan salah satu program yang sangat penting artinya bagi kemajuan suatu bangsa. Kota Makassar merupakan salah satu kota yang laju pertumbuhan penduduknya meningkat setiap tahunnya. Jumlah penduduk kota Makassar pada tahun 2015 mencapai 1.449.401 jiwa, tahun 2016 jumlah penduduk meningkat menjadi 1.469.601 jiwa, dan di tahun 2017 meningkat lagi menjadi 1.489.011 jiwa.

Dinas Pengendalian Penduduk dan Keluarga Berencana Kota Makassar merupakan unsur pemerintahan di bidang pengendalian penduduk dan keluarga berencana yang menjadi kewenangan daerah. Dinas Pengendalian Penduduk dan Keluarga Berencana mempunyai tugas membantu Walikota melakukan urusan pemerintahan di bidang pengendalian penduduk dan keluarga berencana.

Dalam menjalankan tugasnya Dinas Pengendalian Penduduk dan Keluarga Berencana Kota Makassar dibantu oleh tenaga fungsional yaitu penyuluh keluarga berencana. Penyuluh keluarga berencana memegang tugas yang sangat penting dalam melaksanakan program $\mathrm{KB}$ di lapangan. Keberhasilan pelaksanaan program KB tidak terlepas dari penyuluh keluarga berencana.

Kinerja penyuluh keluarga berencana kota Makassar masih belum optimal karena ada beberapa penyuluh yang menangani beberapa wilayah sekaligus dan hal ini menunjukkan bahwa masih kurangnya tenaga fungsional penyuluh keluarga berencana. Tujuan penelitian ini untuk mengetahui dan menganalisis Kinerja Penyuluh Keluarga Berencana pada Dinas Pengendalian Penduduk dan Keluarga Berencana Kota Makassar.

\section{METODE PENELITIAN}

Penelitian ini menggunakan metode kualitatif bersifat deskriptif kualitatif, adapun informan dalam penelitian ini berjumlah enam orang yang terdiri dari satu orang kepala Dinas Pengendalian Penduduk dan Keluarga Berencana, satu orang kepala UPT Keluarga Berencana Kecamatan Biringkanaya, satu orang pegawai Sub Bidang pada Dinas PPKBD (Pengendalian Penduduk dan Keluarga Berencana Daerah), satu orang Penyuluh Keluarga Berencana Kelurahan Pai dan dua orang masyarakat. 
Adapun teknik pengumpulan data yang digunakan dalam penelitian ini menggunakan wawancara, telaah dokumen, dan observasi. Instrument pengumpulan data yang digunakan yaitu menggunakan pedoman wawancara, telaah dokumen dan observasi serta teknik analisis data dengan cara reduksi data, penyajian data, menarik kesimpulan dan verifikasi setelah ini menguji keabsahan data dengan teknik triangulasi.

\section{HASIL PENELITIAN}

Hasil dari penelitian ini merupakan jawaban atas pertanyaan-pertanyaan yang diajukan oleh peneliti kepada informan. Adapun sub fokus terdiri dari kuantitas kerja, kualitas dari hasil, kerja sama, dan tanggung jawab.

\section{Kuantitas Kerja}

Kuantitas kerja menurut Wilson dan Heyyel (1987:101) adalah jumlah kerja yang dilaksanakan oleh seseorang pegawai dalam suatu periode tertentu. Hal ini dapat dilihat dari hasil kerja pegawai dalam kerja penggunaan waktu tertentu dan kecepatan dalam menyelesaikan tugas dan tanggung jawabnya. Kuantitas kerja sangat diperlukan di dalam organisasi untuk mengukur kinerja pegawainya. Kuantitas kerja dapat dilihat dari kecepatan dan kemampuan seorang pegawai.
Dengan demikian kuantitas kerja dapat dilihat dari jumlah kerja dan penggunaan waktu. Jumlah kerja adalah banyaknya tugas pekerjaanya, dapat dikerjakan. Penggunaan waktu adalah banyaknya waktu yang digunakan dalam menyelesaikan tugas dan pekerjaan.

Kecepatan kerja merupakan kemampuan seorang individu untuk mengerjakan suatu pekerjaan dengan batas waktu tertentu. Pentingnya kecepatan kerja bagi penyuluh keluarga berencana agar penyuluh keluarga berencana bisa lebih mengatur rencana kerjanya dengan baik, agar target-target yang telah ditetapkan bisa dicapai. Sebagaimana yang diungkapkan oleh. Ibu Hj. Musliah Yusuf selaku Kepala UPT Keluarga Berencana Kecamatan Biringkanaya, bahwa:

"Kalau para penyuluh keluarga
berencana pada kecamatan
Biringkanaya sudah bekerja dengan
cepat karena mereka dikejar oleh target
untuk mencapai angka kredit, karena
mereka kan penyuluh dan mereka
bekerja karena ada nilai angka kredit,
semakin cepat mereka bekerja dan
semakin banyak kegiatan yang
dilakukan akan menambah banyak nilai
angka kredit yang mereka dapatkan akan
menunjang mereka untuk kenaikan
pangkat." (wawancara, 30 Oktober
2018).

Berdasarkan wawancara di atas dapat dikatakan bahwa kecepatan kerja penyuluh keluarga berencana sudah cepat karena penyuluh langsung dipantau oleh pusat 
menggunakan aplikasi E-Visum dan ada target yang harus mereka kejar untuk mencapai nilai angka kredit yang bisa digunakan untuk menunjang kenaikan pangkat. Selain kecepatan, kemampuan kerja juga menjadi salah satu faktor pendukung kinerja penyuluh keluarga berencana dimana kemampuan dilihat berdasarkan kapasitas yang dimiliki oleh seorang individu untuk mengerjakan berbagai tugas dalam suatu pekerjaan. Penyuluh keluarga berencana sudah tergolong mampu dalam tugasnya karena sebelum turun kelapangan sudah dibekali pengetahuan dan wawasan dalam pelatihan dasar umum, namun masih ada penyuluh keluarga berencana yang mungkin masih harus selalu meningkatkan keahliannya lagi dengan mempelajari tupoksinya masingmasing agar lebih paham dengan pekerjaannya.

\section{Kualitas Dari Hasil}

Kualitas dari hasil merupakan seberapa baik seorang pegawai dalam mengerjakan yang seharusnya mereka kerjakan. Kualitas dari hasil sangat dibutuhkan oleh suatu organisasi karena itu bisa menjadi sasaran ukuran berhasil tidaknya kinerja pegawai di dalamnya. Kualitas dari hasil dapat dilihat dari kerapihan dan ketelitian.
Kerapihan merupakan sesuatu yang dilakukan secara baik, teratur, dan tertib. Kerapihan juga sangat menunjang kualitas dari hasil kerja penyuluh keluarga. Selain kerapihan, penyuluh juga dituntut untuk teliti dalam bekerja, dimana ketelitian merupakan kemampuan seseorang individu untuk melakukan suatu pekerjaan dengan teliti dengan tidak ada kesalahan. Sebagaimana yang diungkapkan oleh Ibu Ir. Sarlina Parerung selaku Penyuluh Keluarga Berencana pada Kelurahan Pai, bahwa:

"Saya sudah bekerja dengan cukup teliti apalagi ketika menginput data atau kegiatan kedalam aplikasi, kita harus betul-betul teliti karena kalau salah dan tidak sesuai maka tidak ada nilai angka kredit yang didapatkan." (wawancara, 30 Oktober 2018).

Berdasarkan wawancara diatas dapat dikatakan bahwa penyuluh keluarga berencana sudah bekerja dengan sangat teliti melihat hasil kerjanya yang minim kesalahan.

\section{Kerja Sama}

Kerja sama adalah sesuatu pekerjaan yang dilakukan secara bersama atau pekerjaan yang dilakukan dengan bantuan orang lain untuk mencapai suatu tujuan bersama. Kerja sama dapat dilihat dari jalinan kerja sama dan kekompakan.

Jalinan kerja sama merupakan hubungan timbal balik, saling 
menguntungkan yang terjalin berdasarkan kepedulian, kesetaraan, dan kebersamaan yang sinergis. Guna membantu memperlancar proses kerja penyuluh keluarga berencana pada suatu wilayah dibutuhkan jalinan kerja sama antara penyuluh dengan sub PPKBD dan kader KB yang dipilih secara langsung oleh penyuluh keluarga berencana karena tanpa bantuan sub PPKBD dan Kader KB penyuluh tidak mampu mengerjakan pekerjaannya karena susahnya berkomunikasi, bertemu dan mengumpulkan masyarakat pada suatu wilayah tertentu. Jalinan kerja sama ini sama-sama menguntungkan karena penyuluh dapat terbantu kerjanya, sub PPKBD dan Kader KB pun mendapat kompensasi langsung dari pusat. Didalam kerja sama dibutuhkan juga kekompakan antar mitra, dimana kekompakan merupakan pekerjaan yang dilakukan secara bersama, teratur dan rapih untuk mencapai suatu tujuan, penyuluh keluarga berencana dengan sub PPKBD dan para Kader KB sudah kompak dalam bekerja sama, terlebih lagi penyuluh keluarga berencana selalu memfasilitasi pelatihanpelatihan kecil untuk sub PPKBD dan para Kader KB nya agar pada saat turun ke lapangan sub PPKBD dan para Kader KB sudah paham apa tugasnya dan bisa satu tujuan dengan penyuluh keluarga berencana.

\section{Tanggung Jawab}

Tanggung jawab terhadap pekerjaan adalah kesadaran akan kewajiban pegawai untuk melaksanakan pekerjaan yang diberikan oleh organisasi. Pegawai tidak bisa lepas dari tanggung jawab karena ada tugas pokok dan fungsi yang harus mereka jalani. Tanggung jawab bisa dilihat dari hasil kerja dan pengambilan keputusan.

Hasil kerja merupakan keluaran kerja yang bisa di ukur. Hasil kerja penyuluh keluarga berencana sangat berpengaruh terhadap tanggung jawabnya dalam melakukan suatu pekerjaan. Sebagimana yang dikemukakan oleh Bapak Andi Zulkifli Nanda S.STP., M.Si. selaku kepala Dinas Pengendalian Penduduk dan Keluarga Berencana Kota Makassar, bahwa:
"Sejauh ini hasil kerja penyuluh sudah cukup memuaskan namun memang belum terlalu optimal dikarenakan kurangnya sumber daya penyuluh $\mathrm{kb}$ dan kami masih sangat membutuhkan banyak tenaga fungsional penyuluh terutama yang sifatnya pns agar sasaran kerja organisasi bisa terus tercapai setiap tahunnya" (wawancara, 01 November 2018.)

Adapun yang disampaikan oleh Ibu Hj. Musliah Yusuf selaku Kepala UPT Keluarga Berencana Kecamatan Biringkanaya, bahwa: 
"Hasil kerja penyuluh keluarga berencana pada Kecamatan Biringkanaya memang masih ada yang belum mencapai target untuk akhir tahun, tapi sejauh ini tiap bulannya selalu ada peningkatan capaian peserta KB Aktif diusahakan agar ketika akhir tahun semua target bisa tercapai" (wawancara, 30 Oktober 2018).

Lebih lanjut oleh Ibu Ir. Sarlina Parerung selaku Penyuluh Keluarga Berencana pada Kelurahan Pai, mengemukakan bahwa:

"Kalau hasil kerja rata-rata sih kalau akhir tahun capai target. Biasanya yang tidak capai target perbulan itu karena biasa ada masyarakat misalnya dia tinggal di Sudiang tetapi dia memasang KB di rumah sakit Siloam jadi otomatis dia tidak terdaftar sebagai peserta $\mathrm{KB}$ aktif di wilayah sudiang hal itu yang membuat hasil kerja kita menurun karena dia tidak terdaftar sebagai peserta KB aktif di wilayah tempat tinggalnya." (wawancara, 30 Oktober 2018).

Hal yang sama dikemukakan oleh Ibu Andi Riani selaku Masyarakat yang ber KB pada Kelurahan Pai, Kecamatan Biringkanaya, bahwa:

"Kalau hasil kerja penyuluh KB didaerah ini saya kurang tahu, karena saya belum merasakan hasil kerjanya dan saya memasang KB tidak melalui penyuluh KB didaerah ini. Saya memasang $\mathrm{KB}$ karena inisiatif saya sendiri dan saya memasangnya dirumah sakit dibantu dengan dokter kandungan saya." (wawancara, 05 November 2018).

Berdasarkan wawancara diatas dapat dikatakan bahwa, secara umum hasil kerja penyuluh keluarga berencana sudah baik karena pasangan usia subur yang peserta KB Aktif sudah banyak, namun ada beberapa masyarakat yang memasang alat $\mathrm{KB}$ diluar wilayah tempat tinggalnya, hal ini menyebabkan masyarakat tersebut tidak terdaftar sebagai peserta KB Aktif diwilayah tempat tinggalnya, sehingga jika dilihat dari data yang ada menunjukkan bahwa masih kurang peserta KB Aktif diwilayah tersebut karena masyarakat tersebut terdaftar sebagai peserta KB aktif diwilayah tempat mereka memasang alat KB tersebut. Selain hasil kerja, sikap dalam pengambilan keputusan juga sangat berpengaruh terhadap tanggung jawab penyuluh keluarga berencana atas pekerjaannya. Pengambilan keputusan merupakan upaya yang dilakukan untuk memecahkan masalah, mencari jalan tengah, dan mencari solusi, penyuluh keluarga berencana sudah bijak dalam mengambil keputusan dengan mempertimbangkan beberapa aspek yang ada agar tidak salah dalam mengambil keputusan.

\section{PEMBAHASAN}

Untuk mengetahui kinerja pegawai dalam suatu organisasi publik menjadi sangat penting atau dengan kata lain memiliki nilai yang amat strategis. Informasi mengenai kinerja aparatur dan 
faktor-faktor yang ikut berpengaruh terhadap kinerja aparatur sangat penting untuk diketahui, sehingga pengukuran kinerja aparat hendaknya dapat diterjemahkan sebagai suatu kegiatan evaluasi untuk menilai atau melihat keberhasilan dan kegagalan pelaksanaan tugas dan fungsi yang dibebankan kepadanya. Oleh karena itu evaluasi kinerja merupakan analisis interpretasi keberhasilan dan kegagalan pencapaian kinerja. Dalam suatu organisasi perlu adanya pemisahan antara manajemen puncak dan operasional, sehingga memungkinkan manajemen puncak mengfokuskan konsentrasi pada pengambilan keputusan dan pengarahan. Sedangkan kegiatan operasional sebaiknya dijalankan oleh staf sendiri, dimana masing-masing memiliki misi, sasaran, ruang lingkup, tindakan serta otonominya sendiri. Upaya mengarahkan, membutuhkan orang yang mampu melihat seluruh visi dan peluang serta mampu menyeimbangkan antar berbagai tuntutan yang saling bersaing untuk mendapatkan sumber daya. Hal tersebut membutuhkan personil yang bersungguh-sungguh fokus pada visi, misi dan melaksanakannya dengan baik.

Kata "kinerja" telah menjadi kata yang telah memasyarakat, seringkali istilah kinerja ini, mulai dari media massa, pejabat birokrasi, pelaku bisnis bahkan sampai masyarakat awam, namun demikian tidak ditemukan definisi yang definitif tentang kinerja. Hal ini dikarenakan istilah kinerja tidak ditemui dalam Kamus Besar Bahasa Indonesia. Kecuali kamus bahasa Indonesia lainnya yang menyatakan bahwa kinerja merupakan sesuatu yang dicapai atau prestasi yang diperlihatkan atas kemampuan kerja. Sehingga berbagai pihak cenderung memberikan padanan kata kinerja dengan "performance dalam bahasa Inggris.

Kinerja pada dasarnya dapat dilihat dari dua segi, yaitu kinerja pegawai (perindividu) dan kinerja organisasi. Kinerja pegawai adalah hasil kerja perseorangan dalam suatu organisasi. Sedangkan kinerja organisasi adalah totalitas hasil kerja yang dicapai suatu organisasi.

Mengetahui kinerja pegawai berarti berusaha untuk mempelajari serta memahami kinerja yang dimiliki oleh pegawai dalam sebuah organisasi. Dengan kata lain, mengetahui kinerja pegawai menjadi sangat penting atau memiliki nilai yang amat strategis. Informasi mengenai kinerja pegawai dan indikator-indikator yang ikut berpengaruh terhadap kinerja pegawai sangat penting untuk diketahui, sehingga menganalisis kinerja pegawai hendaknya dapat diterjemahkan sebagai suatu kegiatan evaluasi untuk menilai atau 
melihat keberhasilan dan kegagalan pelaksanaan tugas dan fungsi yang dibebankan kepadanya. Oleh karena itu evaluasi kinerja merupakan analisis interpretasi keberhasilan dan kegagalan pencapaian kinerja.

Kinerja pegawai adalah hasil kerja yang dicapai oleh seluruh pegawai dalam suatu organisasi sesuai dengan wewenang dan tanggung jawab dalam rangka upaya mencapai tujuan organisasi bersangkutan secara legal, tidak melanggar hukum dan sesuai dengan moral maupun etika. Pengertian kinerja pegawai juga dikemukakan oleh Bastian (2001) sebagai gambaran mengenai tingkat pencapaian pelaksanaan tugas pegawai dalam suatu organisasi dalam upaya mewujudkan sasaran, tujuan, misi dan visi organisasi tersebut

Dalam penelitian ini penulis berlandaskan kepada teori yang dikemukakan oleh Mangkunegara (2011: 67) terkait kinerja pegawai yang dapat diukur melalui empat indikator yaitu kuantitas kerja, kualitas dari hasil, kerja sama dan tanggung jawab yang berikut akan diuraikan setiap indikator:

\section{Kuantitas Kerja}

Kuantitas kerja penyuluh keluarga berencana sudah baik, dilihat dari dua indikator yaitu:

\section{a. Kecepatan}

Kecepatan kerja merupakan salah satu aspek yang dapat digunakan untuk mengukur kinerja penyuluh keluarga berencana, karena setiap penyuluh keluarga berencana diberikan tenggat waktu untuk dapat menyelesaikan tugas pokoknya. Apabila penyuluh keluarga berencana dapat menyelesaikan pekerjaannya dengan cepat dan mencapai target maka penyuluh keluarga berencana tersebut memiliki capaian kinerja yang bagus.

Berdasarkan hasil penelitian mengenai kecepatan kerja penyuluh keluarga berencana, penyuluh keluarga berencana telah bekerja dengan cepat hal ini didukung dengan laporan penyelesain kegiatan yang setiap dua jam sekali penyuluh keluarga berencana harus laksanakan dan laporkan langsung melalui aplikasi e-visum yang dimana didalam aplikasi tersebut terdapat target yang telah penyuluh keluarga berencana capai dan perolehan nilai angka kredit yang penyuluh keluarga berencana dapatkan karena telah bekerja dengan cepat, nilai angka kredit bisa digunakan sebagai penunjang kenaikan pangkat untuk penyuluh keluarga berencana dan adapun bukti bahwa sudah ada beberapa penyuluh yang mengalami kenaikan pangkat dikarenakan perolehan nilai angka kreditnya jadi penyuluh keluarga berencan sudah termasuk cepat 
dalam bekerja. Hal ini sejalan dengan teori yang dikemukakan oleh Fadel (2009: 159) bahwa kecepatan kerja harus sangat diperhatikan dengan menggunakan metode, tahapan kerja, maupun target yang telah ditetapkan.

b. Kemampuan

Kemampuan kerja penyuluh keluarga berencana, penyuluh keluarga berencana sudah mampu dalam mengerjakan pekerjaannya karena penyuluh keluarga berencana sebelumnya sudah mengikuti latihan dasar umum yang didalamnya dijelaskan dan diajarkan mengenai pengetahuan, advokasi, dan tata cara penyuluhan yang nanti akan penyuluh keluarga berencana gunakan untuk turun kelapangan melakukan kegiatan penyuluhan, konseling maupun wawancara (tatap muka) langsung kepada masyarakat. Latihan dasar umum ini telah diikuti oleh seluruh penyuluh keluarga berencana sebelum turun kelapangan. Penyuluh keluarga berencana juga sudah mengerti akan tugas pokok dan fungsinya dalam melakukan pekerjaannya sehingga penyuluh keluarga berencana sudah dianggap mampu dan paham untuk melaksanakan kegiatan penyuluhan, konseling maupun wawancara.

Hal ini sejalan dengan teori yang dikemukakan oleh Robbins dalam Pasolong (2007: 186) bahwa Kemampuan dapat dilihat dari dua segi yaitu kemampuan intelektual dan kemampuan fisik, kemampuan intelektual dilihat dari cara seseorang untuk melakukan berbagai aktivitas mental seperti berpikir, menalar dan memecahkan masalah sedangkan kemampuan fisik dilihat dari cara seseorang melakukan tugasnya dengan kecekatan, kekuatan dan keterampilan.

\section{Kualitas dari Hasil}

Kualitas pekerjaan ini berhubungan dengan mutu yang dihasilkan oleh para pegawai dari suatu pekerjaan dalam suatu organisasi, dimana kualitas pekerjaan ini mencerminkan pengukuran tingkat "kepuasan", yakni seberapa baik penyelesaiannya.

Isu mengenai kualitas cenderung menjadi semakin penting dalam menjelaskan kinerja pegawai. Banyak pandangan negatif yang terbentuk mengenai organisasi publik muncul karena kesalahan dari para pegawai itu sendiri baik menyangkut pelayanan, perilaku ataupun kebiasaan yang buruk yang sering diperlihatkan kepada para masyarakat. Dengan demikian, kepuasan pegawai pemerintah terhadap layanan dapat dijadikan indikator kinerja. Keuntungan utama menggunakan kepuasan sumber daya aparatur pemerintah seringkali tersedia secara mudah dan murah. 
Informasi mengenai kepuasan terhadap kualitas pelayanan seringkali dapat diperoleh dari media massa atau hasil dari diskusi publik. Nilai dimana proses atau hasil dari ketelitian dalam melaksanakan pekerjaan kesempurnaan pekerjaan itu sendiri juga bisa dikatakan sebagai kualitas pelayanan. Selain itu kualitas juga bisa diartikan dengan melihat bagaimana pekerjaan dilakukan sesuai dengan perintah sehingga pekerjaan yang dilakukan berdasarkan input yang ada akan mencapai target kerja yang ditetapkan.

Kualitas dari hasil kerja penyuluh keluarga berencana sudah baik, dilihat dari dua indikator yaitu:

\section{a. Kerapihan}

Setiap penyuluh keluarga berencana tentunya diharapkan dalam menjalankan tugasnya dengan berpakaian yang rapih dan sopan agar masyarakat yang melihat penyuluh keluarga berencana pada saat penyuluhan pun bisa tertarik untuk menyimak arahan dari penyuluh mengenai program Keluarga Berencana.

Berdasarkan hasil analisis data yang dilakukan mengenai kerapihan penyuluh keluarga berencana dapat dikatakan bahwa dalam melaksanakan kegiatan penyuluhan, konseling, maupun wawancara penyuluh keluarga berencana telah menggunakan pakaian dinas hariannya seperti pakaian dinas harian warna khaki, LINMAS,
KORPRI kemeja putih dan celana/rok hitam, dan batik, selain dalam berpakaian penyuluh keluarga berencana juga sudah bersikap rapih dalam melakukan pekerjaannya seperti dalam hal menyimpan dokumen-dokumen pendukung kegiatannya pada saat turun di lapangan. Hal ini sejalan dengan Peraturan Menteri Dalam Negeri Nomor 6 Tahun 2016 Tentang Pakaian Dinas Pegawai Negeri Sipil Di Lingkungan Departemen Dalam Negeri dan Pemerintah Daerah yang di dalamnya membahas mengenai kerapihan dalam berpakaian pegawai negeri sipil yang tertuang dalam pasal $12 \mathrm{~A}$ ayat satu dikatakan bahwa penggunaan pakaian dinas di lingkungan kementerian dalam negeri, pemerintah provinsi dan pemerintah kabupaten/kota sebagaimana dimaksud pada pasal dua yaitu hari senin dan selasa pegawai menggunakan pakaian dinas harian warna khaki, pada hari rabu pegawai menggunakan pakaian dinas harian kemeja warna putih, celana/rok hitam atau gelap, pada hari kamis dan jumat pegawai menggunakan pakaian dinas harian batik/tenun/pakaian khas daerah, adapun pakaian LINMAS digunakan sesuai dengan pada saat peringatan hari LINMAS, pakaian KORPRI digunakan pada saat peringatan hari KORPRI atau sesuai acara. 


\section{b. Ketelitian}

Didalam melakukan pekerjaan penyuluh keluarga berencana diharapkan dapat bekerja dengan teliti agar pekerjaan yang dilakukan minim kesalahan dan akan mendapat hasil yang berkualitas. Berdasarkan hasil penelitian yang telah dilakukan penyuluh keluarga berencana telah bekerja dengan teliti melihat hasil kerja yang telah dilakukan oleh penyuluh keluarga berencana sudah minim akan kesalahan karena pada saat penyuluh keluarga berencana melakukan kegiatan penyuluhan, konseling maupun wawancara dan harus mendata serta menginput laporan kegiatannya sebelum itu penyuluh keluarga berencana selalu melakukan pengecekan ulang sebelum menginput hasil kegiatannya pada aplikasi yang telah disediakan maupun pada dokumen-dokumen yang terlampir yang harus dikumpulkan. Hal ini sejalan dengan yang dikemukakan oleh Fadel (2009:159) di dalam melakukan tugasnya pegawai bukan hanya dituntut untuk bekerja dengan cepat, namun dalam menyelesaikan tugasnya pegawai juga dituntut untuk teliti dalam bekerja dan selalu melakukan pengecekan ulang agar tidak ada terjadi kesalahan.

\section{Kerja Sama}

Kerja sama penyuluh keluarga berencana dengan mitra kerja sudah terjalin dengan baik dilihat dari dua indikator yaitu: a. Jalinan Kerja Sama

Kemitraan merupakan jalinan kerja sama dari dua belah pihak atau lebih yang melibatkan hubungan timbal balik yang saling menguntungkan yang terjalin berdasarkan kepedulian dan kebersamaan yang sinergis. Jalinan kerja sama untuk penyuluh keluarga berencana juga merupakan salah satu faktor penting dalam terwujudnya suatu tujuan yang diinginkan yaitu terlaksananya tugas pokok dan fungsi dalam organisasi agar berjalan dengan sistematis serta mengurangi beban pekerjaan dari pegawai juga untuk mengoptimalkan hasil kerja yang diinginkan. Berdasarkan hasil analisis data mengenai jalinan kerja sama penyuluh keluarga berencana, penyuluh keluarga berencana sudah menjalin kerja sama yang baik dengan mitra kerjanya seperti sub PPKBD dan Kader KB yang dipilih secara langsung oleh penyuluh keluarga berencana untuk membantu melaksanakan tugasnya di lapangan seperti dalam hal penyuluhan, konseling maupun pendampingan saat wawancara bersama masyarakat. Adapun hasil penelitian terdahulu oleh Afniyanty (2016: 7) yang sejalan dengan penelitian ini mengatakan bahwa Penyuluh keluarga 
berencana pada Desa Pakawa sudah memiliki jalinan kerja sama yang baik dengan mitra kerja di lapangan dalam melaksanakan pekerjaannya.

\section{b. Kekompakan}

Kekompakan merupakan pekerjaan yang dilakukan secara bersama, senada, dan rapih untuk mencapai suatu tujuan tertentu. Berdasarkan hasil analisis data mengenai kekompakan penyuluh keluarga berencana, penyuluh keluarga berencana sudah bekerja dengan sangat kompak dengan mitra kerjanya seperti sub PPKBD dan Kader KB hal ini dibuktikan dengan adanya hubungan saling ketergantungan antara penyuluh keluarga berencana, sub PPKBD dan Kader KB. Terlebih lagi dalam hal menjaga kekompakan penyuluh keluarga berencana selalu memfasilitasi pelatihan-pelatihan kecil untuk sub PPKBD dan Kader KB guna memberikan wawasan dan pengetahuan agar pada saat turun kelapangan penyuluh keluarga berencana, sub PPKBD dan Kader KB bisa kompak dan bersatu padu dalam perkataan dan tindakan jika menanggapi suatu perkara, masalah maupun keluhan yang datang dari masyarakat. Hal ini sejalan dengan penelitian terdahulu yang dikemukakan oleh Dewi (2007: 46) bahwa Kekompakan merupakan pekerjaan yang dilakukan secara teratur, rapih dan bersatu dalam menghadapi atau mengerjakan suatu pekerjaan yang ditandai dengan adanya sikap saling ketergantungan.

\section{Tanggung Jawab}

Tanggung jawab penyuluh keluarga berencana dalam bekerja sudah baik dilihat dari dua indikator yaitu:

a. Hasil Kerja

Hasil kerja penyuluh keluarga berencana, dimana hasil kerja penyuluh keluarga berencana belum terlalu optimal karena masih kurangnya tenaga fungsional penyuluh keluarga berencana, hal ini menyebabkan adanya penyuluh keluarga berencana yang menangani dua wilayah sekaligus, namun hal ini tidak membuat turun semangat penyuluh keluarga berencana dalam melalukan pekerjaannya melainkan membuat penyuluh keluarga berencana lebih termotivasi untuk selalu meningkatkan capaian hasil kerjanya seperti capaian peserta KB Baru, KB Aktif dan KB MKJP agar target pertahun yang ditentukan bisa dicapai dan nilai angka kreditnya bisa meningkat. Hal ini sejalan dengan teori yang dikemukakan oleh Mangkunegara (2010: 10) bahwa Tujuan penelitian hasil kerja seorang pegawai untuk mengevaluasi, mencatat dan mengakui hasil kerja seorang pegawai sehingga mereka termotivasi untuk berbuat lebih baik lagi atau sekurang-kurangnya bisa mendapatkan prestasi. 
b. Pengambilan Keputusan

Setiap keputusan mempunyai kadar tingkatan yang berbeda-beda. Keputusan biasanya memiliki empat tingkatan yaitu keputusan otomatis, keputusan yang berdasarkan informasi yang diharapkan, keputusan yang berdasarkan pertimbangan, serta keputusan berdasarkan ketidakpastian ganda. Keputusan otomatis merupakan bentuk keputusan yang dibuat dengan sangat sederhana. Keputusan besarkan informasi yang diharapkan merupakan tingkatan keputusan yang telah mempunyai informasi yang sedikit kompleks, artinya informasi yang ada telah memberi aba-aba untuk mengambil keputusan. Akan tetapi keputusan belum dibuat karena informasi perlu dipelajari terlebih dahulu. Keputusan berdasarkan berbagai pertimbangan merupakan tingkat keputusan yang lebih banyak membutuhkan informasi dan informasi tersebut dikumpulkan serta dianalisis untuk dipertimbangkan agar menghasilkan keputusan. Ia membandingkan harganya, kualitasnya serta modelnya dan untuk mengambil keputusan mungkin ia akan memerlukan waktu beberapa jam bahkan beberapa hari sebelum menjatuhkan keputusan. Keputusan berdasarkan ketidakpastian ganda, merupakan tingkat keputusan yang paling kompleks. Jumlah informasi yang diperlukan semakin banyak selain itu, dalam informasi yang sudah ada terdapat ketidakpastian. Keputusan semacam ini lebih banyak mengandung risiko dan terdapat keraguan dalam pengambilan keputusannya.

Cara pengambilan keputusan penyuluh keluarga berencana, penyuluh keluarga berencana sudah bersikap bijak dalam mengambil keputusan yang sebelumnya telah melalui berbagai pertimbangan-pertimbangan. Selain itu penyuluh keluarga berencana juga melibatkan lingkungan organisasi seperti Kepala UPT Keluarga Berencana Kecamatan dan teman-teman penyuluh keluarga berencana lainnya untuk mengambil keputusan yang tepat jika mendapat keluhan atau complain dari masyarakat. Hal ini sejalan dengan teori yang dikemukakan oleh Gibson et.al (1997: 103) bahwa pengambilan keputusan sebagai proses pemikiran dan pertimbangan mendalam yang dihasilkan dalam sebuah keputusan, pengambilan keputusan merupakan sebuah proses dinamis yang dipengaruhi oleh bentuk kekuatan termasuk lingkungan organisasi, pengetahuan, kecakapan, dan motivasi.

Dari uraian tentang cara pengukuran indikator kinerja di atas maka dapat disimpulkan bahwa penerapan indikator kinerja merupakan proses identifikasi dan klasifikasi indikator kinerja melalui sistem 
pengumpulan dan pengolahan data/infomasi untuk menentukan capaian tingkat kinerja program organisasi. Di samping itu, berdasarkan review literatur sebagaimana dijelaskan dapat disimpulkan bahwa setiap organisasi dibentuk untuk mencapai tujuan yang ditetapkan. Keberhasilan organisasi dalam mencapai tujuan dapat diketahui dengan menggunakan evaluasi atau penilaian kegiatan organisasi tersebut berdasarkan peraturan, norma dan etika yang berlaku. Penilaian kinerja dalam kurun waktu tertentu ini disebut dengan pengukuran kinerja organisasi. Hasilnya dapat dijadikan pedoman perbaikan kegiatan organisasi.

\section{KESIMPULAN DAN SARAN}

Berdasarkan hasil penelitian yang dilakukan, maka dapat disimpulkan bahwa kinerja penyuluh keluarga berencana pada Dinas Pengendalian Penduduk dan Keluarga Berencana Kota Makassar yang terdiri dari kuantitas kerja sudah baik melihat kemampuan penyuluh keluarga berencana dalam menyelesaikan tugasnya sudah cepat sesuai dengan target waktu yang telah ditentukan. Selanjutnya, kualitas dari hasil kerja sudah baik melihat kerapihan dan ketelitian penyuluh keluarga berencana dalam mendata dan menginput hasil kegiatan sudah minim akan kesalahan. Lalu, kerja sama penyuluh keluarga berencana dengan mitra kerjanya sudah terjalin dengan baik dan sangat kompak. Terakhir, tanggung jawab penyuluh keluarga berencana jika dilihat dari caranya dalam mengambil keputusan sudah bijak dengan mempertimbangkan berbagai hal sebelum mengambil keputusan lalu melihat hasil kerjanya belum optimal namun penyuluh keluarga berencana akan terus berupaya meningkatkan hasil kerjanya agar bisa maksimal

Adapun saran dalam penelitian ini yaitu diharapkan agar penyuluh keluarga berencana bisa lebih meningkatkan kemampuannya, meningkatkan ketelitian dalam bekerja agar tidak ada kesalahan yang terjadi, menguatkan jalinan kerja sama dengan mitra kerjanya, meningkatkan hasil kerjanya dan untuk pemerintah agar bisa menambah tenaga fungsional khususnya penyuluh keluarga berencana agar hasil kerja penyuluh keluarga berencana bisa lebih maksimal.

\section{REFERENSI}

Afniyanty. 2016. Kinerja Petugas Lapangan Keluarga Berencana (PLKB) di Desa Pakawa Kecamatan Pasangkayu Kabupaten Mamuju Utara. Jurnal Katalogis.

Bastian, 2001, Akuntansi Sektor Publik di Indonesia, Yogyakarta, BPFE.

Dewi, Andayani. 2007. Analisis Faktor-Faktor yang Mempengaruhi Produktivitas Tenaga Kerja di Sumatera Utara. Skripsi. Medan: Universitas Sumatera Utara 
Fadel, Muhammad. 2009. Reinventing Government (Pengalaman dari Daerah). Jakarta: Elex Media Komputindo

Gibson, James L, et al. 1997. Organisasi (Perilaku Struktur dan Proses. Alih Bahasa: Nanuk Adiarni. Jakarta: Binarupa Aksara

Mangkunegara, Anwar Prabu. 2010. Manajemen Sumber Daya Perusahaan. Bandung: Remaja Rosdakarya

Mangkunegara, Anwar Prabu. 2011. Evaluasi Kinerja Sumber Daya Manusia Cetakan Ketiga. Bandung: Refika Aditama

Pasolong, Harbani. 2007. Teori Administrasi Publik. Bandung: Alfabeta.

Willson dan Heyyel. 1987. Hand Book Of Modern Office Management and Administration Service. Mc Graw Hill Inc. New Jersey. 